\title{
The Brain Chondroitin Sulfate Proteoglycan Brevican Associates with Astrocytes Ensheathing Cerebellar Glomeruli and Inhibits Neurite Outgrowth from Granule Neurons
}

\author{
Hidekazu Yamada, Barbara Fredette, Kenya Shitara, Kazuki Hagihara, Ryu Miura, Barbara Ranscht, \\ William B. Stallcup, and Yu Yamaguchi
}

The Burnham Institute, La Jolla, California 92037

\begin{abstract}
Brevican is a nervous system-specific chondroitin sulfate proteoglycan that belongs to the aggrecan family and is one of the most abundant chondroitin sulfate proteoglycans in adult brain. To gain insights into the role of brevican in brain development, we investigated its spatiotemporal expression, cell surface binding, and effects on neurite outgrowth, using rat cerebellar cortex as a model system. Immunoreactivity of brevican occurs predominantly in the protoplasmic islet in the internal granular layer after the third postnatal week. Immunoelectron microscopy revealed that brevican is localized in close association with the surface of astrocytes that form neuroglial sheaths of cerebellar glomeruli where incoming mossy fibers interact with dendrites and axons from resident neurons. In situ hybridization showed that brevican is synthesized by these astrocytes themselves. In primary cultures of cerebellar astrocytes, brevican is detected on the
\end{abstract}

surface of these cells. Binding assays with exogenously added brevican revealed that primary astrocytes and several immortalized neural cell lines have cell surface binding sites for brevican core protein. These cell surface brevican binding sites recognize the $\mathrm{C}$-terminal portion of the core protein and are independent of cell surface hyaluronan. These results indicate that brevican is synthesized by astrocytes and retained on their surface by an interaction involving its core protein. Purified brevican inhibits neurite outgrowth from cerebellar granule neurons in vitro, an activity that requires chondroitin sulfate chains. We suggest that brevican presented on the surface of neuroglial sheaths may be controlling the infiltration of axons and dendrites into maturing glomeruli.

Key words: brevican; chondroitin sulfate proteoglycan; cerebellar development; glomerulus; astrocytes; neurite outgrowth
A diverse array of proteoglycans is expressed in developing and adult brain (Herndon and Lander, 1990; Margolis and Margolis, 1993). Among these, the aggrecan family proteoglycans or "lecticans" (Ruoslahti, 1996) are especially diverse and abundant. Lecticans are a family of chondroitin sulfate proteoglycans (CSPGs) characterized by the presence of an N-terminal hyaluronan-binding domain and a $\mathrm{C}$-terminal lectin-like domain. Four lectican family proteoglycans, namely, aggrecan (Doege et al., 1987), versican (Zimmermann and Ruoslahti, 1989), neurocan (Rauch et al., 1992), and brevican (Yamada et al., 1994), have been defined by molecular cloning.

Brevican was first cloned from adult bovine brain (Yamada et al., 1994). Since then, rat brevican (Yamada et al., 1995) and a glycosylphosphatidylinositol (GPI)-anchored variant of brevican (Seidenbecher et al., 1995) have been cloned. A putative brainspecific hyaluronan-binding protein (BEHAB) (Jaworski et al., 1994) has turned out to be a partial brevican cDNA (Yamada et al., 1995). Like neurocan, the expression of brevican is highly specific to the nervous system (Jaworski et al., 1994; Yamada et al., 1994; Seidenbecher et al., 1995). Although aggrecan and versican are also expressed in the nervous system (Bode-

\footnotetext{
Received May 5, 1997; revised July 18, 1997; accepted July 31, 1997.

This work was supported by National Institutes of Health Grant NS32717 to Y.Y. and Program Project Grant HD25938 to B.R., W.B.S., and Y.Y. We thank Drs Louis F. Reichardt and Bruce Caterson for their gifts of antibodies.

Correspondence should be addressed to Dr. Yu Yamaguchi, The Burnham Institute, 10901 North Torrey Pines Road, La Jolla, CA 92037.

Copyright (C) 1997 Society for Neuroscience $0270-6474 / 97 / 177784-12 \$ 05.00 / 0$
}

Lesniewska et al., 1996; Li et al., 1996), they are mainly expressed in various connective tissues.

A number of studies have indicated that CSPGs have inhibitory effects on neurite outgrowth from various neuronal cell types and that the glycosaminoglycan moieties of these molecules are required for these effects (Carbonetto et al., 1983; Akeson and Warren, 1986; Verna et al., 1989; Snow et al., 1990), although there are a few exceptions (Katoh-Semba and Oohira, 1993; Faissner et al., 1994). Inhibition of axon growth in vivo often occurs at specific sites in the nervous system, referred to as "barriers." Chondroitin sulfates have been implicated as active components of barriers that cause the repulsion of advancing axons in vivo (Snow et al., 1990, 1991; Oakley and Tosney, 1991; Perris et al., 1991; Brittis et al., 1992).

In this paper, we explored the physiological role of brevican by investigating its spatiotemporal expression, cell surface expression, and effects on neurite outgrowth. These studies demonstrated that brevican is produced by astrocytes that form the neuroglial sheaths around cerebellar glomeruli and is bound to astrocytic surfaces by the interaction with "receptors" that recognizes its core protein. Temporally, the expression of brevican coincides with the maturation of glomeruli. Our observations suggest that, being presented on the surface of neuroglial sheaths, brevican may control outgrowth of dendrites and axons from surrounding granule neurons into maturing glomeruli. We propose that brevican may play a crucial role in the maturation of the mossy fiber system in the cerebellum and that cell surface binding may be a general paradigm for maintaining the neurite outgrowth inhibitory activities of secreted CSPGs under tight spatial control. 


\section{MATERIALS AND METHODS}

Materials. Protease-free chondroitinase $\mathrm{ABC}$ and hyaluronidase from Streptomyces hyalurolyticum were purchased from Seikagaku America (Rockville, MD). Heparinase (heparinase I), heparitinase (heparinase III), poly-L-lysine (type VIIB), tosyl chloride-activated agarose, HAT (hypoxanthine, aminopterine, and thymidine) and HT (hypoxanthine and thymidine) media supplements, and mouse monoclonal antibody isotyping reagents were obtained from Sigma (St. Louis, MO). Precast gels for SDS-PAGE were purchased from Novex (San Diego, CA). BCA protein assay reagents and Vectastain $\mathrm{ABC}$ kits were purchased from Pierce (Rockford, IL) and from Vector Laboratories (Burlingame, CA), respectively. The MPL + TDM adjuvant was purchased from RIBI ImmunoChem (Hamilton, MT). The hybridoma cloning factor was purchased from IGEN (Rockville, MD). Phosphatidylinositol-specific phospholipase C (PI-PLC), digoxigenin RNA-labeling mixtures, alkaline phosphatase-conjugated anti-digoxigenin antibodies, and basic fibroblast growth factor were purchased from Boehringer Mannheim (Indianapolis, IN). ${ }^{125}$ I-Labeled goat anti-mouse IgG was purchased from New England Nuclear (Boston, MA). Purified mouse laminin and OptiMEM were purchased from Life Technologies (Gaithersburg, MD). The HA (hyaluronan assay) test kit was obtained from Pharmacia (Uppsala, Sweden). Rabbit antibodies to glutamate decarboxylase (GAD) and glial fibrillary acidic protein (GFAP) were purchased from Chemicon (Temecula, CA) and Accurate Chemicals (Westbury, NY), respectively. Anti-chicken B-cadherin monoclonal antibody 5A6 (Murphy-Erdosh et al., 1994) and anti-chondroitin 4-sulfate monoclonal antibody 2B6 (Couchman et al., 1984) were kind gifts from Dr. L. F. Reichardt (University of California, San Francisco) and Dr. B. Caterson (University of Wales, Cardiff, UK), respectively.

Isolation of total soluble proteoglycans and the $80 \mathrm{kDa} C$-terminal brevican core protein. The total proteoglycan fraction was isolated from soluble extracts of rat brain at various ages by a protocol using DEAESepharose chromatography and sequential washing steps, as described originally by Herndon and Lander (1990). Details of the protocol have been published previously (Yamada et al., 1994). Final eluents from DEAE-Sepharose by a $0.2-1 \mathrm{M} \mathrm{NaCl}$ gradient were combined as total soluble proteoglycans. Yields of total proteoglycans were 10, 15, 16, 15, and $17 \mu \mathrm{g} / \mathrm{gm}$ of brain tissue (wet weight) for postnatal day 0 (P0), P7, P14, P21, and adult, respectively (see the experiments shown in Fig. 2). For binding assays (see Figs. 6, 7), we used a brevican-enriched mixed proteoglycan preparation. This preparation was derived from one of the fractions of the $0.2-1 \mathrm{M} \mathrm{NaCl}$ eluents from DEAE-Sepharose. Because brevican elutes from DEAE-Sepharose earlier than most other proteoglycans, we chose a fraction that is most enriched for brevican relative to other proteoglycans by analyzing eluents in SDS-PAGE and immunoblotting after chondroitinase $\mathrm{ABC}$ digestion. This fraction, in which brevican comprises $\sim 50 \%$ of the total proteins, was then dialyzed against PBS and used in binding assays. For neurite outgrowth assays (see Fig. 9), purified brevican prepared by immunoaffinity chromatography was used (see Immunochemical techniques below). For purification of the $80 \mathrm{kDa}$ $\mathrm{C}$-terminal fragment of brevican core protein, the total soluble proteoglycan fraction from adult rat was first digested with chondroitinase $\mathrm{ABC}$ and then fractionated on a Vydac C4 column in the Shimadzu LC600 HPLC system as described previously (Yamada et al., 1995). Combined fractions containing purified $80 \mathrm{kDa}$ fragment were lyophilized in a Speed-Vac concentrator (Savant, Farmingdale, NY) and dissolved in PBS. Protein concentrations were determined by using BCA protein assay reagents with BSA as the standard.

Monoclonal and polyclonal antibodies to brevican. BALB/c mice were immunized with $50 \mu \mathrm{g}$ of the HPLC-purified $80 \mathrm{kDa} C$-terminal fragment of brevican core protein mixed with MPL + TDM adjuvant. After three boosts with the same antigen preparation, spleen cells were prepared from the immunized mice used for polyethyleneglycol-mediated fusion with P3x63Ag8.653 myeloma cells that had been cultured in "growth medium" [DMEM containing $10 \%$ heat-inactivated fetal calf serum (FCS), $2 \mathrm{~mm}$ glutamine, $100 \mathrm{U} / \mathrm{ml}$ penicillin, $100 \mathrm{mg} / \mathrm{ml}$ streptomycin, $50 \mu \mathrm{M} \beta$-mercaptoethanol, and $1 \mathrm{~mm}$ sodium pyruvate]. Fused hybridoma cells were plated in 96 well plates and cultured in the "selection medium" (growth medium plus $10 \%$ cloning factor and $1 \times$ HAT) for 7-10 d. Culture supernatants from wells containing visible colonies were screened by ELISA (see Immunochemical techniques for details). Cells in the wells that showed a positive reaction in ELISA were then subjected to cloning by limiting dilution in growth medium containing $10 \%$ cloning factor and $1 \times \mathrm{HT}$. After rescreening by immunoblotting against chondroitinase $\mathrm{ABC}$-digested total soluble brain proteoglycans, clones showing specific reactivity to the 145 and $80 \mathrm{kDa}$ brevican core protein bands were recloned to establish stable hybridoma lines. During the course of expansion of cells after the second cloning, the concentration of cloning factor was gradually reduced to $0 \%$. Established hybridomas were maintained in growth medium containing $1 \times$ HT. Subclasses of monoclonal antibodies were determined with the mouse monoclonal antibody isotyping reagents kit. A clone designated RB18 has been shown to produce IgG1 antibodies to brevican core protein (see Results). Another clone designated Mb6 produces IgG1 antibodies that recognize the stubs of chondroitin sulfate chains that are generated by chondroitinase digestion. Mb6 antibodies that do not recognize undigested brevican have been used as one of the controls.

Ascites fluid was obtained from BALB/c mice injected with RB18 hybridoma cells. After clarification by centrifugation, ascites fluid was brought up to $3 \mathrm{M} \mathrm{NaCl}$ and $100 \mathrm{~mm}$ Tris- $\mathrm{HCl}, \mathrm{pH} 8.9$, and applied to a protein A-Sepharose column ( $6 \mathrm{ml}$ bed volume) preequilibrated with 100 $\mathrm{mm}$ Tris- $\mathrm{HCl}, \mathrm{pH} 8.9$, containing $3 \mathrm{M} \mathrm{NaCl}$. After washing the column first with $100 \mathrm{~mm}$ Tris- $\mathrm{HCl}, \mathrm{pH} 8.9$, containing $3 \mathrm{M} \mathrm{NaCl}$ and then with $10 \mathrm{~mm}$ Tris- $\mathrm{HCl}, \mathrm{pH} 8.9$, containing $3 \mathrm{M} \mathrm{NaCl}$, we eluted bound materials with $100 \mathrm{~mm}$ glycine- $\mathrm{HCl}, \mathrm{pH} 3.0$, and quickly neutralized them.

Rabbit antibodies to rat brevican were raised by immunizing with the HPLC-purified $80 \mathrm{kDa}$ core protein. Specific antibodies were affinity purified by incubating the crude antisera with nitrocellulose filters blotted with the $80 \mathrm{kDa}$ core protein according to the method of Yamada et al. (1994).

Immunochemical techniques. Immunoblotting was performed as described previously (Yamada et al., 1994). For ELISA, each well of the 96 well plates was coated for $2 \mathrm{hr}$ at $22^{\circ} \mathrm{C}$ with $100 \mu \mathrm{l}$ of chondroitinase $\mathrm{ABC}$-digested total soluble proteoglycans isolated from adult rat brain (5 $\mu \mathrm{g} / \mathrm{ml})$. After the wells were blocked with $1 \%$ BSA, they were incubated with undiluted hybridoma culture supernatants at $50 \mu \mathrm{l} /$ well for $1 \mathrm{hr}$ at $22^{\circ} \mathrm{C}$. After being washed with PBS containing $0.05 \%$ Tween 20 , the wells were incubated with alkaline phosphatase-conjugated anti-mouse IgG. Bound antibodies were detected by hydrolysis of phosphatase substrate. For immunoaffinity purification of brevican, purified RB18 IgG was coupled to tosyl chloride-activated agarose (10 $\mathrm{mg}$ of $\mathrm{IgG} / \mathrm{ml}$ of agarose) according to the method of Nilsson and Mosbach (1984). Total soluble proteoglycan fractions from adult rat brain were applied to the RB18 immunoaffinity column, and after the column was washed with PBS and with $100 \mathrm{~mm}$ glycine-HCl, pH 3.0, bound brevican was eluted with 100 $\mathrm{mm}$ triethanolamine- $\mathrm{HCl}, \mathrm{pH} 11.5$. Eluates were quickly neutralized and then post-cleared of leached antibodies by passing through protein ASepharose in the presence of $3 \mathrm{M} \mathrm{NaCl}$. Post-cleared brevican samples were dialyzed against PBS and used for substrates in the neurite outgrowth assay. For preparation of brevican core proteins, a portion of the sample was digested with chondroitinase $\mathrm{ABC}$ as described previously (Yamada et al., 1994) and dialyzed against PBS to remove chondroitin sulfate fragments.

Immunohistochemistry. For immunolocalization of brevican, cerebella of P0, P7, P14, P21, P28, and adult (P180) rats were dissected, embedded in OCT compound (Miles, Elkhart, IN), and quickly frozen in dry ice-cooled isopentane. Twelve-micrometer-thick sections were cut and stored at $-70^{\circ} \mathrm{C}$ until use. Immediately before immunostaining, the sections were microwave-irradiated in the presence of $2 \%$ paraformaldehyde (Barsony and Marx, 1990). Fixed sections were blocked with 3\% normal horse serum in PBS and then incubated with RB18 anti-brevican hybridoma culture supernatant at 1:5 dilution for $1 \mathrm{hr}$. After being washed three times with PBS, sections were incubated with biotinylated horse anti-mouse $\operatorname{IgG}$ for $30 \mathrm{~min}$, washed, and then reacted with the complex of avidin and biotinylated peroxidase for $30 \mathrm{~min}$. Bound antibodies were visualized by incubating with diaminobenzidine and $\mathrm{H}_{2} \mathrm{O}_{2}$. Some sections were counterstained with hematoxylin for 2 min to visualize cell nuclei. Immunostaining with anti-GAD antibodies was performed according to the protocol provided by the supplier of the antibody. Briefly, cerebella were dissected from adult rats, perfusion-fixed with $4 \%$ paraformaldehyde, and embedded in OCT compound. Freefloating frozen sections were incubated with the antibody for $20 \mathrm{hr}$, followed by biotinylated horse anti-rabbit IgG and the avidin-biotin complex as described above. Immunostaining with anti-GFAP antibodies was performed as described for anti-GAD antibodies, except that sections were stained after mounting on glass slides. The numbers of GADand GFAP-positive cells in the granular layer were counted using a $63 \times$ objective, and the density of these cells per square millimeter of the granular layer was calculated.

Immunoelectron microscopy. Adult rats were deeply anesthetized with 
sodium pentobarbital and perfused transcardially with $500 \mathrm{ml}$ of calciumfree Ringer's buffer, followed by $500 \mathrm{ml}$ of fixative consisting of $4 \%$ formaldehyde, $0.2 \%$ glutaraldehyde, and $0.12 \mathrm{M}$ phosphate buffer, $\mathrm{pH} 7.3$, and a second $500 \mathrm{ml}$ of $4 \%$ formaldehyde and $0.12 \mathrm{M}$ phosphate buffer. The brains were fixed in situ for $1 \mathrm{hr}$. Cerebella were dissected and vibratome-sectioned sagittally at a thickness of $50 \mu \mathrm{m}$ in the sagittal plane. Sections were collected in PBS and incubated for $1 \mathrm{hr}$ in PBS containing 5\% normal goat serum (PBS/NGS), followed by a $48 \mathrm{hr}$ incubation at $4^{\circ} \mathrm{C}$ in anti-brevican hybridoma supernatant diluted 1:5 in PBS/NGS. The sections were rinsed with $0.1 \mathrm{~m}$ Tris, $\mathrm{pH}$ 7.6, containing $77 \mathrm{~mm} \mathrm{NaCl}$ [Tris-buffered saline (TBS)] and incubated in biotinylated horse anti-mouse IgG diluted in PBS/NGS for $1 \mathrm{hr}$ at room temperature, followed by rinsing in TBS. The sections were then incubated with the complex of avidin and biotinylated peroxidase for $1 \mathrm{hr}$ at room temperature. Finally, the sections were reacted in $0.05 \%$ diaminobenzidine and $0.001 \%$ hydrogen peroxide in TBS and rinsed in $0.13 \mathrm{M}$ phosphate buffer for subsequent processing by standard electron microscopy methods. Briefly, the sections were incubated for $1 \mathrm{hr}$ each in $2 \%$ osmium tetroxide in phosphate buffer and $1 \%$ uranyl acetate in $\mathrm{H}_{2} \mathrm{O}$, ethanol-dehydrated, and flat-embedded between Mylar plastic sheets in a TAAB/Epon resin mixture $(1: 1)$. After polymerization at $65^{\circ} \mathrm{C}$, desired regions containing the granule cell layer were cut out, reembedded on larger plastic blocks, and thin-sectioned on a Reichardt Ultracut microtome. The thin sections were viewed and photographed with an Hitachi $600 \mathrm{E}$ transmission electron microscope.

In situ hybridization. A 380 bp XbaI-XhoI fragment of rat brevican cDNA (corresponding to nucleotides 1337-1717; Yamada et al., 1995) was subcloned into pBluescript IIKS + . The resulting subclone was linearized by digestion with $X b a \mathrm{I}$ (for antisense probes) or XhoI (for sense probes), and cRNA was transcribed in vitro with T3 and T7 polymerases, respectively, using a digoxigenin RNA-labeling mixture. The procedures for hybridization on paraffin-embedded sections were described previously (Watanabe et al., 1995). Immunological detection of hybridized probes was performed with alkaline phosphatase-conjugated anti-digoxigenin antibodies in the presence of polyvinyl alcohol (De Block and Debrouwer, 1993).

Cell culture. Primary cultures of astrocytes were prepared from P0 rat cerebella according to the method of McCarthy and de Vellis (1980). Cerebellar granule neurons were isolated according to the method of Stallcup and Beasley (1985). Cultures of these cells were characterized by staining with tetanus toxin and with anti-GFAP as described previously (Yamada et al., 1994). Rat neural cell lines B28, B35, and B50, all derived

A

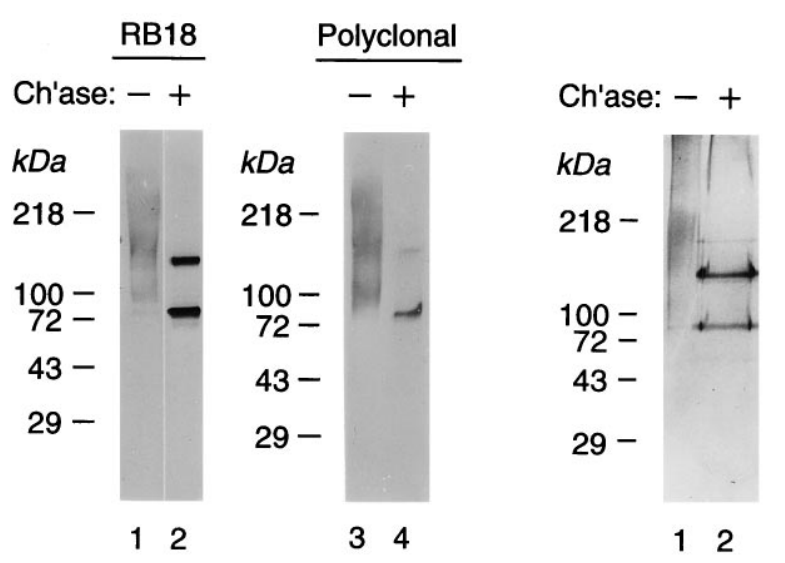

Figure 1. Reactivities of RB18 monoclonal antibodies and affinitypurified polyclonal antibodies to rat brevican. $A$, Immunoblotting with RB18 and affinity-purified anti-brevican antibodies. Soluble extracts from adult rat brain without (lanes 1,3) or with (lanes 2, 4) chondroitinase $\mathrm{ABC}$ digestion were resolved in $8-16 \%$ gradient gels and immunoblotted with RB18 culture supernatants (1:20 dilution; lanes 1, 2) or affinitypurified rabbit anti-rat brevican antibodies $(5 \mu \mathrm{g} / \mathrm{ml}$; lanes 3,4$) . B$, SDS-PAGE analysis of brevican purified from adult rat brain. Eluents from RB18 immunoaffinity column were analyzed in an $8-16 \%$ gradient gel without (lane 1) or with (lane 2) chondroitinase ABC digestion. Bands were visualized by silver staining. from the CNS of the BDIX rat (Schubert et al., 1974), and Chinese hamster ovary $(\mathrm{CHO})$ cells were cultured in DMEM containing $10 \%$ FCS.

Binding assay. Cerebellar astrocytes and granule neurons were plated in wells that had been treated with $0.1 \mathrm{mg} / \mathrm{ml}$ poly-L-lysine at $7 \times 10^{4}$ cells/well $24 \mathrm{hr}$ before experiments. B28, B35, B50, and CHO cells were plated similarly in wells without poly-L-lysine coating. Cells were first washed twice with DMEM containing $2 \%$ FCS and $20 \mathrm{~mm}$ HEPES, $\mathrm{pH}$ 7.3 (washing buffer; all of the subsequent washing and dilution of reagents were done with this buffer). Undigested or digested brevicanenriched fractions diluted in $100 \mu \mathrm{l}$ of washing buffer (protein at 36 $\mu \mathrm{g} / \mathrm{ml}$ ) were added to each well and incubated for $2 \mathrm{hr}$ at $37^{\circ} \mathrm{C}$. After the incubation, cells were washed three times and then incubated with RB18 or control monoclonal antibodies at $10 \mu \mathrm{g} / \mathrm{ml}$ for $1 \mathrm{hr}$ at $37^{\circ} \mathrm{C}$. Control antibodies included 5A6, anti-chicken B-cadherin (Murphy-Erdosh et al., 1994); 2B6, anti-chondroitin sulfate "stub" antibody (Couchman et al., 1984); and Mb6 (see above). After washing, cells were incubated for $1 \mathrm{hr}$ with [ ${ }^{125} \mathrm{I}$ ]goat anti-mouse $\mathrm{IgG}$ at $5 \mu \mathrm{l} /$ well $(0.083 \mu \mathrm{Ci} / \mu \mathrm{l})$. Cells were then washed once with washing buffer, washed twice with PBS, and solubilized in $1 \mathrm{~m} \mathrm{NaOH}$. Radioactivity in the lysates was counted on a gamma counter. In some experiments, cells were treated with various glycosaminoglycan lyases (hyaluronidase, heparinase, heparitinase, and chondroitinase $\mathrm{ABC}$ ) before the binding assay. All treatments with glycosaminoglycan lyases were performed for $1 \mathrm{hr}$ at $37^{\circ} \mathrm{C}$ in OptiMEM at $100 \mu \mathrm{l} /$ well with the following concentrations of enzymes: hyaluronidase, 10 and 20 turbidity reducing units (TRU)/ml; heparinase, $5 \mathrm{U} / \mathrm{ml}$; heparitinase, $1 \mathrm{U} / \mathrm{ml}$; and chondroitinase $\mathrm{ABC}, 50 \mathrm{mU} / \mathrm{ml}$. Effectiveness of hyaluronidase digestion was ascertained by measuring cell-associated hyaluronan using the Pharmacia HA test kit (Watanabe and Yamaguchi, 1996). Treatment with hyaluronidase at 10 and $20 \mathrm{TRU} / \mathrm{ml}$ has been shown to remove 90 and $96 \%$ of cell-associated hyaluronan, respectively, from B28 cells. For PI-PLC treatment, monolayers of cells were incubated for $1 \mathrm{hr}$ at $37^{\circ} \mathrm{C}$ with $2 \mathrm{U} / \mathrm{ml}$ PI-PLC in OptiMEM at $100 \mu \mathrm{l} /$ well as described previously (Koller and Ranscht, 1996). Effectiveness of the PI-PLC treatment was ascertained by measuring the removal of contactin from the cell surface.

Neurite outgrowth. Substrates for the neurite outgrowth assay were
A

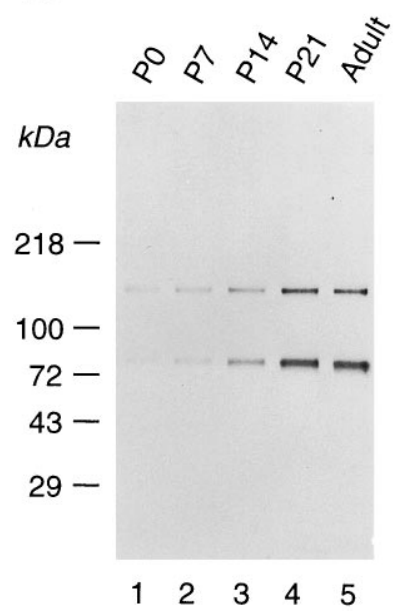

B

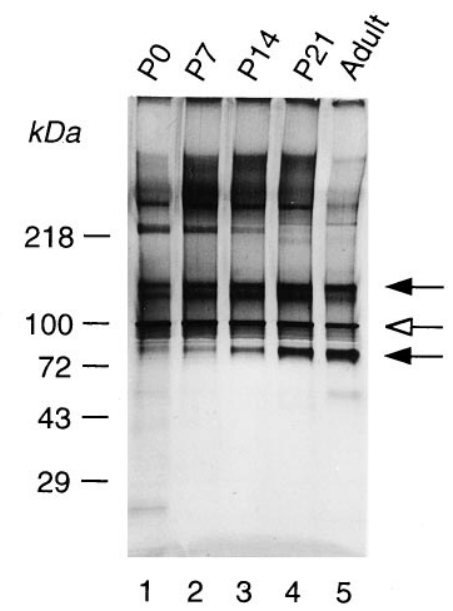

Figure 2. Developmental changes in brevican present in rat brain extracts. $A$, Immunoblotting analysis of brevican expression in developing rat brain. Total soluble proteoglycan fractions from rat brain at different ages were prepared according to the method of Yamada et al. (1994) and were digested with chondroitinase ABC. Digested materials were resolved in an $8-16 \%$ gel and immunoblotted with RB18 monoclonal antibody. The amount of sample loaded in each lane was normalized for the wet weight of starting brain tissues. $B$, Profile of CSPG core proteins expressed in developing and adult rat brain. Aliquots of the total soluble proteoglycans were analyzed in $8-16 \%$ gradient gels after chondroitinase ABC digestion. Bands were visualized by silver staining. The 145 and 80 $\mathrm{kDa}$ brevican core proteins are indicated (filled arrows). A band that migrated at $100 \mathrm{kDa}$ (open arrow) is chondroitinase $\mathrm{ABC}$. As described in $A$, the amounts of samples were normalized for the wet weight of starting brain tissues. 


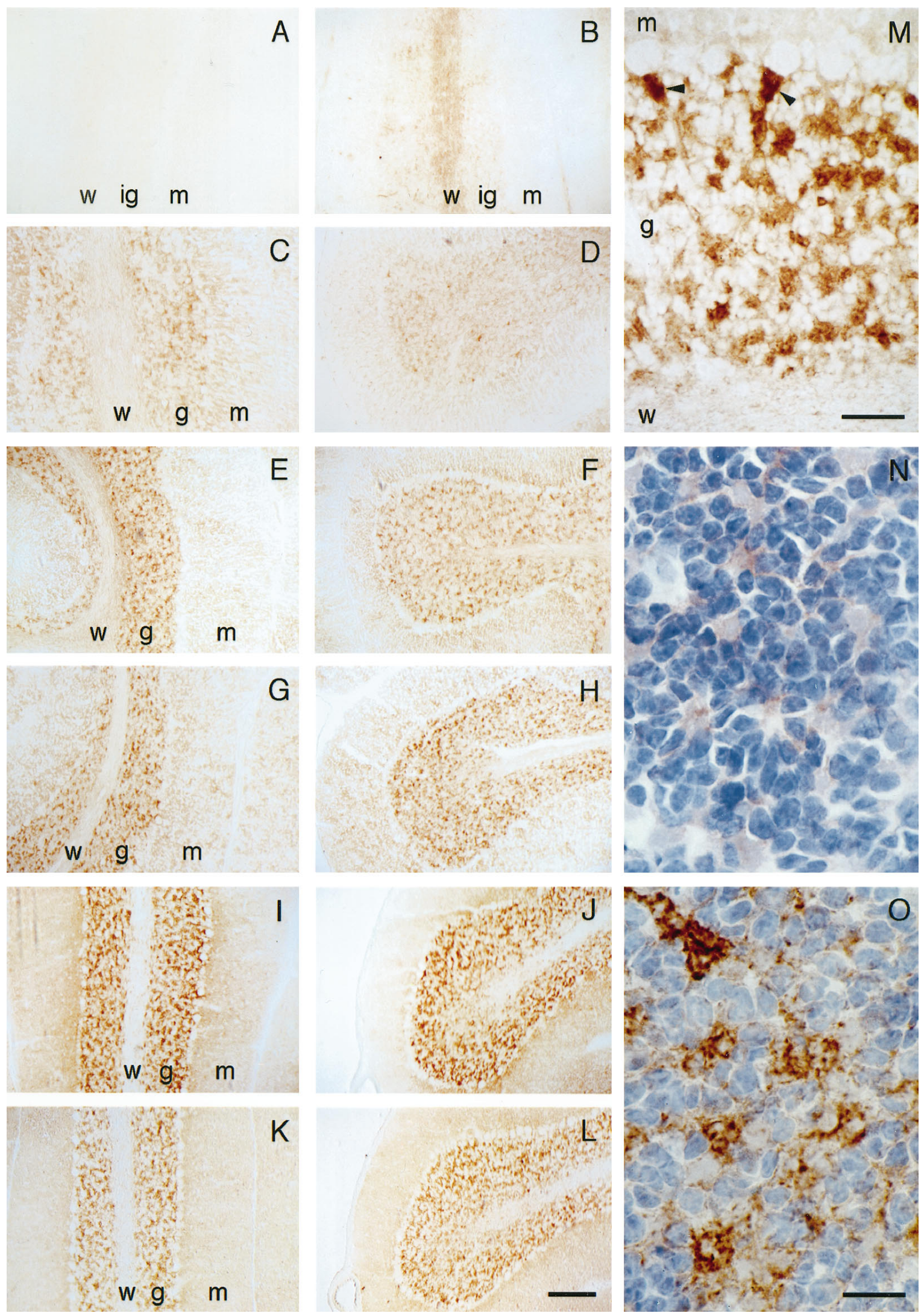

Figure 3. Immunolocalization of brevican in developing cerebellum. $A-L$, Developmental changes in brevican expression in cerebellar cortex. Frozen sections of postnatal rat cerebella were stained with anti-rat brevican monoclonal antibody RB18 $(A-J)$ or affinity-purified anti-rat brevican polyclonal antibody $(K, L)$ by the ABC method. $A, \mathrm{P} 14 ; B, \mathrm{P} 21 ; C, D, \mathrm{P} 28 ; E, F, \mathrm{P} 35 ; G, H, \mathrm{P} 60 ; I-L, \mathrm{P} 180$. Scale bar, $100 \mu \mathrm{m}$ (marked in $L)$. Note that brevican immunoreactivity is predominantly localized in the granular layer after P28 $(C-L)$. In P21 cerebellum, moderate staining was detected in the presumptive white matter $(B)$. In later stages, little staining was detected in the white matter. No brevican immunoreactivity (Figure legend continued) 
prepared on nitrocellulose-coated culture dishes according to the method of Snow et al. (1990). Five square centimeters of nitrocellulose membrane (Schleicher \& Schuell, Keene, NH) were dissolved in $6 \mathrm{ml}$ of methanol. A $60 \mathrm{~mm}$ culture dish was coated with $0.4 \mathrm{ml}$ of this nitrocellulose solution and allowed to dry under a laminar flow tissue culture hood. To prepare test substrates on the nitrocellulose-coated dish, we first mixed samples to be tested with $50 \mu \mathrm{g} / \mathrm{ml}$ (final concentration) mouse laminin in PBS. Strips of Whatman No. 4 filter paper $(1 \times 10 \mathrm{~mm})$ were soaked with $10 \mu \mathrm{l}$ of these mixed solutions per strip and placed on the nitrocellulose-coated dish. After $5 \mathrm{~min}$, the filter strips were removed, and a $2 \times 2 \mathrm{~cm}$ area surrounding the test substrate was spread evenly with $50 \mu \mathrm{l}$ of $50 \mu \mathrm{g} / \mathrm{ml}$ laminin solution using a bent Pasteur pipette. The dish was then washed twice with DMEM containing 10\% FCS. Cerebellar granule neurons isolated as described above were plated onto the dishes at $\sim 7 \times 10^{4}$ cells $/ \mathrm{cm}^{2}$ in DMEM containing $10 \% \mathrm{FCS}, 25 \mathrm{mM} \mathrm{KCl}$, and $20 \mathrm{ng} / \mathrm{ml}$ basic fibroblast growth factor. After $36 \mathrm{hr}$, the cultures were photographed under phase-contrast optics.

\section{RESULTS}

\section{Reactivity of RB18 monoclonal antibody with brevican}

In both rat and bovine brain, brevican core protein exists as a 145 $\mathrm{kDa}$ full-length form and an $80 \mathrm{kDa} \mathrm{C}$-terminal fragment that is generated by proteolytic cleavage in the central nonglobular domain (Yamada et al., 1994, 1995). The $80 \mathrm{kDa}$ core protein fragment, which contains most of the central domain as well as the entire C-terminal globular domain, can be purified by HPLC. Its cleavage site has been identified by $\mathrm{N}$-terminal amino acid sequencing (Yamada et al., 1994, 1995). We generated hybridoma lines from mice immunized with the HPLC-purified $80 \mathrm{kDa}$ brevican core protein. Among several hybridoma clones established, one clone producing IgG1 antibodies (designated RB18) was selected for the present studies. In immunoblotting of soluble extracts from adult rat brain, RB18 reacts with a diffuse smear typical of proteoglycans (Fig. $1 A$, lane 1 ). After treatment of samples with chondroitinase $\mathrm{ABC}, \mathrm{RB} 18$ recognizes two bands of 145 and $80 \mathrm{kDa}$ (lane 2), corresponding to the core proteins of bovine and rat brevican (Yamada et al., 1994, 1995). These two bands were also recognized by polyclonal antibodies raised against rat brevican core protein (lane 4). Although polyclonal antibodies show a stronger reactivity to the $80 \mathrm{kDa}$ fragment than to the $145 \mathrm{kDa}$ core protein, $\mathrm{RB} 18$ recognizes both forms equally well. An affinity column of RB18 purifies brevican from the total soluble proteoglycan fraction (Fig. $1 B$ ). We conclude that RB18 recognizes an epitope present in the $\mathrm{C}$-terminal region of rat brevican core protein and that it can recognize not only the core protein but also intact brevican-carrying chondroitin sulfate chains. RB18 does not show any cross-reactivities with other members of the aggrecan family present in rat brain extracts (Fig. $1 A$; see also Fig. 2).

\section{Developmental expression of brevican in postnatal rat brain}

We first examined the temporal expression of brevican in postnatal brain in relation to other CSPGs. Total soluble proteoglycan fractions were isolated from whole brains at different developmental stages and digested with chondroitinase ABC. This material was analyzed by silver staining for the presence of various CSPG core proteins and by immunoblotting for the specific presence of brevican. Immunoblotting showed that little brevican is detected at $\mathrm{P} 0$ but that the amount of brevican increases steadily with development (Fig. $2 A$ ). The quantity of the $80 \mathrm{kDa}$ form relative to the $145 \mathrm{kDa}$ form increases in the later stages of development. In the adult brain, the $80 \mathrm{kDa}$ form is more abundant than the full-length form. A similar, but more pronounced, developmentally regulated proteolytic processing has been reported for neurocan (Rauch et al., 1991).

SDS-PAGE analysis showed a marked change in the expression pattern of CSPG core proteins during postnatal development and in the abundance of brevican relative to other CSPGs (Fig. 2B). Although CSPG core proteins at 300, 220, 145, and $125 \mathrm{kDa}$ are expressed approximately equally in the brain during early postnatal stages (P0-P7), the 145 and $80 \mathrm{kDa}$ bands of brevican become more abundant in later stages (P14-P21). In adult brain (P180), the $80 \mathrm{kDa}$ brevican core protein is by far the most abundant species. Taken together, these analyses demonstrated that brevican is one of the most abundant CSPGs in adult rat brain.

\section{Spatiotemporal expression of brevican in rat cerebellum}

With its well defined laminar tissue architecture, developing cerebellum is an excellent system to examine spatiotemporal expression patterns of molecules, especially those involved in cell adhesion and migration. The pattern of cell migration and the sequence of layer formation during cerebellar histogenesis are known in considerable detail (for review, see, Altman, 1972). Also, our initial experiments have shown that, although brevican is widely expressed in the brain, expression in the cerebellar cortex is most remarkable in terms of its level and spatial organization. Therefore we expected the cerebellar cortex to provide information that would be most useful for understanding the biological roles of brevican.

We examined rat cerebella from P7 to P180 by immunoperoxidase staining with RB18 antibodies. Consistent with the immunoblotting results, little brevican immunoreactivity was detected in P7 (data not shown) and P14 (Fig. 3A) cerebellar sections. At $\mathrm{P} 21$, moderate brevican immunoreactivity is detected in the presumptive white matter (Fig. $3 B$ ). The internal granular layer also shows brevican staining, but it is weaker than that in the presumptive white matter. Significant staining for brevican is first detected in the granular layer of P28 cerebellum (Fig. 3C,D). At this stage, migration of granule cells has essentially been completed, and the external granular layer has disappeared (Altman, 1972). No brevican immunoreactivity was found in the external granular layer at any stage we examined. The intensity of the staining in the internal granular layer increases significantly from P28 to P60 (Fig. $3 E-J$ ). Even after P35, a stage by which the histogenesis of cerebellar cortex is all but completed (Altman, 1972), brevican immunoreactivity still shows a gradual increase in its intensity

\footnotetext{
was observed in P14 cerebellum $(A) . M$, High-magnification view of adult (P180) cerebellar cortex immunostained with RB18 antibody. Note that brevican immunoreactivity is localized in the granular layer, coinciding with protoplasmic islets. Occasionally, regions corresponding to the first segments of Purkinje cell axons, or pinceau, show very intense staining (arrowheads). Scale bar, $50 \mu \mathrm{m}$. $N, O$, High-magnification views of the granular layer in $\mathrm{P} 21(N)$ and P180 $(O)$ cerebellar sections immunostained with RB18 antibody followed by counterstaining with hematoxylin to visualize granule cell nuclei. Note that, in P21 cerebellum, protoplasmic islets (stained pale blue with hematoxylin) are still small and exhibit only weak brevican immunoreactivity. In adult cerebellum, protoplasmic islets occupy much larger spaces than in P21 cerebellum. Intense immunoreactivity of brevican is observed in these matured protoplasmic islets. Clusters of granule cells are negative for brevican immunoreactivity. Scale bar, $20 \mu \mathrm{m}$. $m$, Molecular layer; $g$, granular layer; ig, internal granular layer (before P21); $w$, white matter.
} 
(Fig. 3G-J). In adult cerebellum (P180), intense reticular staining was observed throughout the granular layer (Fig. 3I,J,M). Affinity-purified rabbit anti-brevican antibodies gave a staining pattern in adult cerebellum identical to that seen with monoclonal antibody (Fig. $3 K, L$ ). Under higher magnification, the staining for brevican appears to coincide with cell-free areas in the granular layer called protoplasmic islets. In addition, the basal poles of Purkinje cells occasionally show intense staining (Fig. 3M, arrowheads). This staining, having a conical shape covering the basal pole of the Purkinje cell soma, apparently corresponds to the structure called "pinceau," where the descending collaterals of a basket cell axon form synapses with the first segment of the Purkinje cell axon (Palay and Chan-Palay, 1974). No brevican immunoreactivity was observed on the apical side of the Purkinje cell soma, along the Bergmann glial fibers, or in the molecular layer throughout the period from P14 to P180.

More-detailed localization of brevican was investigated in adult cerebellar sections counterstained with hematoxylin. This staining allows differentiation between granule cell soma and cell-free neuropil in the granular layer. This analysis revealed that the intense staining of brevican found in the granular layer indeed coincides with the location of protoplasmic islets (Fig. $3 \mathrm{O}$ ). The protoplasmic islet is a cell-free area in the granular layer that contains one or more glomeruli, each of which consists of a central mossy fiber rosette with surrounding granule cell dendrites and Golgi cell axons (Palay and Chan-Palay, 1974). Brevican immunoreactivity appears to cover protoplasmic islets, whereas little immunoreactivity was observed within clusters of granule cells (Fig. 3O). At P21, when protoplasmic islets are still small, only weak brevican immunoreactivity was detected (Fig. 3N).

\section{Immunoelectron microscopic localization of brevican in adult rat cerebellar cortex}

To determine the localization of brevican in the glomerulus more precisely, we performed indirect immunoelectron microscopy on adult rat cerebellar sections. Under low magnification, brevican immunoreactivity was detected surrounding glomeruli in the protoplasmic islet (Fig. 4A). This pattern of distribution corresponds to the location of the neuroglial processes that ensheathe each glomerulus (Palay and Chan-Palay, 1974; Landis, 1983). Lamellar processes of these astrocytes separate one glomerulus from another in the islet and interweave with granule cell dendrites and Golgi cell axons at the periphery of the glomerulus (Palay and Chan-Palay, 1974). Consistent with this histological description, brevican immunoreactivity is detected along the interface between individual glomeruli as well as between a glomerulus and granule cell somata. Brevican immunoreactivity is mostly restricted to the outer surface of glomeruli and is rarely found deep inside glomeruli, a distribution pattern also consistent with that of neuroglial sheaths (Palay and Chan-Palay, 1974).

On close examination, we found that brevican immunoreactivity occurs along the profile of neuroglial processes that follow the peripheral contours of glomeruli (Fig. 4B). Brevican immunoreactivity seems to associate closely with the surface of these processes (opposing arrows). Little reaction product is found inside the mossy rosette, including the interfaces between granule cell dendrites, between a granule cell dendrite and Golgi cell axon, or between granule cell dendrites and the mossy fiber.

\section{In situ hybridization demonstrates that astrocytes forming neuroglial sheaths express brevican mRNA}

The immunoelectron microscopy results suggest that astrocytes ensheathing glomeruli provide the cellular origin of brevican in
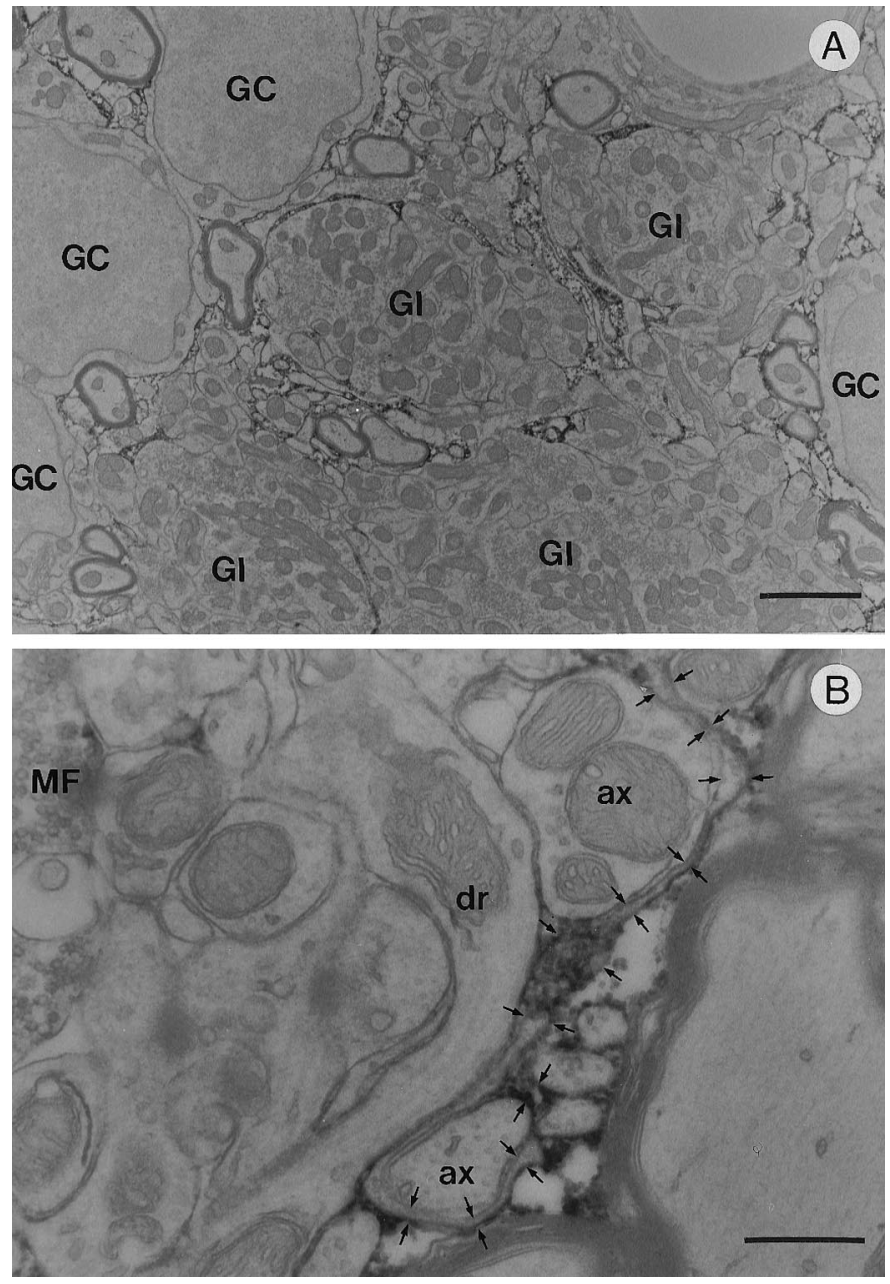

Figure 4. Immunoelectron microscopic analysis of brevican in glomeruli. Formaldehyde- and glutaraldehyde-fixed sections were stained with antibrevican monoclonal antibody RB18 by the $\mathrm{ABC}$ method as described in Materials and Methods. $A$, Low-magnification view of a protoplasmic islet containing several glomeruli. Note that brevican immunoreactivity surrounds each glomerulus in the protoplasmic islet. The interior of the glomeruli and contact sites between granule cells are negative for brevican staining. $G C$, Granule cells; $G I$, glomerulus. Scale bar, $2 \mu \mathrm{m}$. $B$, High-magnification view of the periphery of a glomerulus. Note that glial processes (opposing arrows) ensheathe the glomerulus and that brevican immunoreactivity is observed along these glial processes. $M F$, Mossy fiber; $a x$, Golgi cell axon; $d r$, granule cell dendrites. Scale bar, $0.5 \mu \mathrm{m}$.

the granular layer. This notion is consistent with our previous observation that primary cultures of cerebellar astrocytes express brevican mRNA (Yamada et al., 1994). To confirm the origin of brevican synthesis, we performed in situ hybridization. Positively labeled cells are relatively sparsely distributed in the granular layer, clearly not coinciding with the numerous granule cells present in this layer (Fig. 5A). No positive signals were detected in granule cells or blood vessels in the granular layer. Under high magnification, labeled cells show circular and semicircular shapes surrounded by granule cells, occasionally showing labeled processes extending outward (Fig. $5 B-E$ ).

The pattern of distribution and the morphology of the labeled cells are consistent with the properties of astrocytes forming neuroglial sheaths. However, there is a possibility that the labeled cells could be Golgi cells, which are also sparsely distributed in the granular layer. To rule out this possibility, we compared the 
Figure 5. In situ hybridization analysis of the brevican mRNA expression. Formaldehyde-fixed paraffin sections of adult rat cerebellum were hybridized with a digoxigenin-conjugated rat brevican RNA probe that was visualized with phosphatase-conjugated anti-digoxigenin antibodies. $A$, Low-magnification view of the granular layer. Note that positively labeled cells are rather sparsely distributed throughout the granular layer. Many of these labeled cells show peculiar circular or semicircular shapes. Scale bar, 40 $\mu \mathrm{m}$. $B-E$, High-magnification views of positively labeled cells with typical circular or semicircular shape. Note that positively labeled cells surround a cell-free zone and granule cells, which are localized outside these labeled cells, are negative for brevican mRNA expression. Occasionally, a few processes are found extending from these circular or semicircular structures $(B-D)$. Scale bar, $20 \mu \mathrm{m}$.
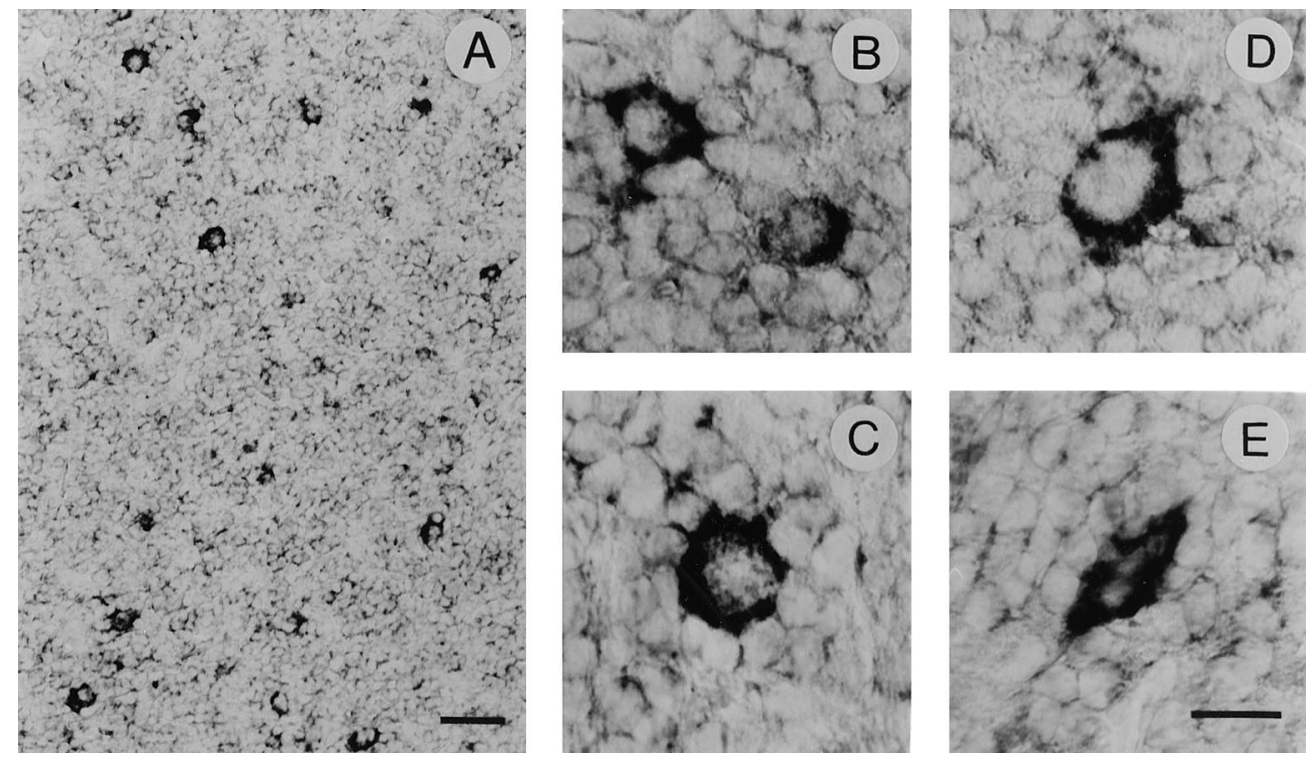

Figure 6. Cerebellar astrocytes in culture express brevican on their surface. $A$, Binding assays were performed as described in Materials and Methods. Primary cultures of cerebellar astrocytes (filled columns) or cerebellar granule neurons (hatched columns) were incubated without additions $(-)$, with the total soluble proteoglycan fraction $(P G)$, or with core proteins of the total soluble proteoglycan fraction $(C P)$ from rat brain. Bound brevican was detected with RB18 antibody and $\left[{ }^{125} \mathrm{I}\right]$ goat anti-mouse $\mathrm{IgG}$. Control monoclonal antibodies used in these experiments were 2B6 and Mb6, both of IgG1 subclass. Background binding was determined in an assay without addition of exogenous proteoglycans or first antibodies. Background binding in this experiment was 960 and $1100 \mathrm{cpm}$ for astrocytes and neurons, respectively. Data represent means of duplicate determinations of net binding (i.e., total binding minus background binding). $B$, The PI-PLC treatment does not release endogenous cell-associated brevican from astrocytes. Monolayers of primary astrocytes were treated without $(-)$ or with $(+)$ PI-PLC $(2 \mathrm{U} / \mathrm{ml})$ for $1 \mathrm{hr}$ at $37^{\circ} \mathrm{C}$ as described previously (Koller and Ranscht, 1996). The amount of cell surface brevican after PI-PLC digestion was assayed with RB18 antibodies. Data represent means $\pm \mathrm{SD}(n=3)$.

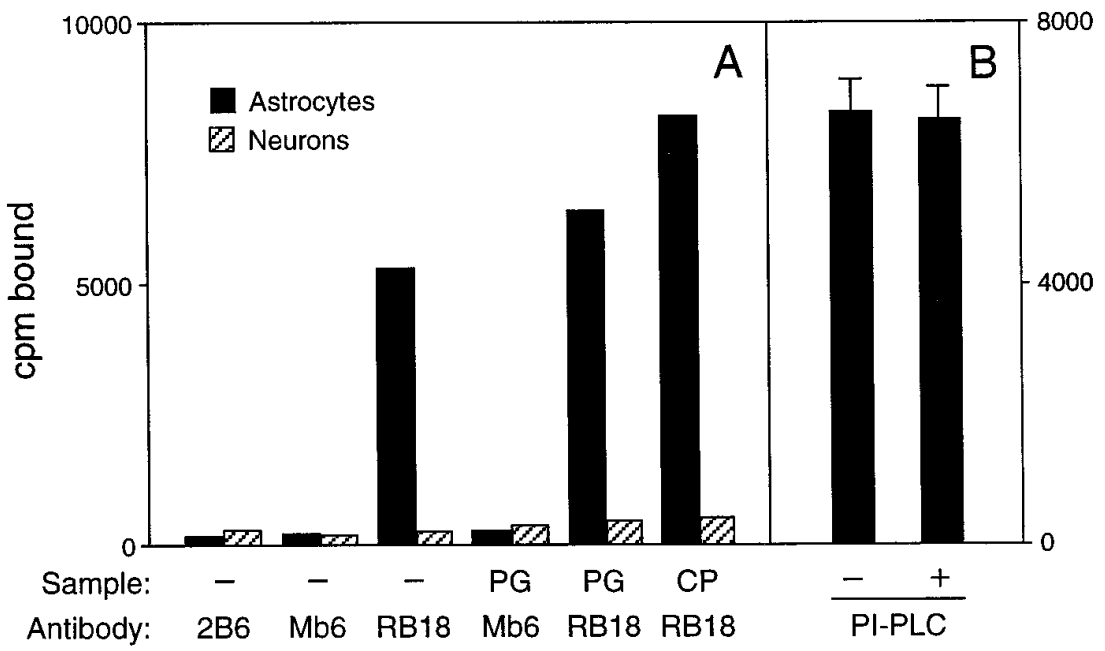

density of Golgi cells with that of brevican mRNA-positive cells in the granular layer. Antibodies to GAD were used to identify Golgi cells. In the granular layer, GAD is expressed in Golgi cells but not in granule cells or astrocytes (Takayama, 1994). Although the anti-GAD antibody also stains Purkinje cells, these cells can be readily identified by their location. For comparison, we also determined the density of GFAP-positive cells.

The results of this analysis showed that brevican mRNApositive cells occur at a density of $10.1 \pm 1.3$ cells $/ \mathrm{mm}^{2}$ or 0.933 cells for every Purkinje cell. Compared with these numbers, GFAP-positive cells occur at a density of $11.3 \pm 2.3$ cells $/ \mathrm{mm}^{2}$ or 1.043 cells for every Purkinje cell. These results demonstrate that the density of brevican mRNA-positive cells is in good agreement with that of GFAP-positive cells. In contrast, the density of GAD-positive cells (excluding Purkinje cells) is $2.7 \pm 0.9$ cells/ $\mathrm{mm}^{2}$ or 0.258 cells for every Purkinje cell, approximately four times lower than that of brevican mRNA-positive cells. The density of GAD-positive cells obtained in this analysis was close to the published frequency of Golgi cells $(\sim 0.3$ Golgi cells for every Purkinje cell; Palay and Chan-Palay, 1974). By correlation, these results confirm that cells positive for brevican mRNA are astrocytes and not Golgi cells.

\section{Astrocytes express brevican on their surfaces}

The close association of brevican with astrocyte surfaces demonstrated by immunoelectron microscopy suggests that brevican may interact with the surface of astrocytes. To test this possibility, we performed antibody binding assays with rat cerebellar astrocytes in culture. As shown in Figure $6 A$, RB18 antibodies bind to astrocytes without addition of exogenous brevican (third filled column from the left), whereas control antibodies do not (first and second filled columns). These results suggest that astrocytes express endogenous brevican on their surfaces. Because there is a GPI-anchored isoform of brevican (Seidenbecher et al., 1995), it might be suspected that this isoform represents the brevican molecules associated with astrocyte surfaces. However, several lines of evidence indicate that this is not the case. First, we have shown previously that primary cultures of cerebellar astrocytes 

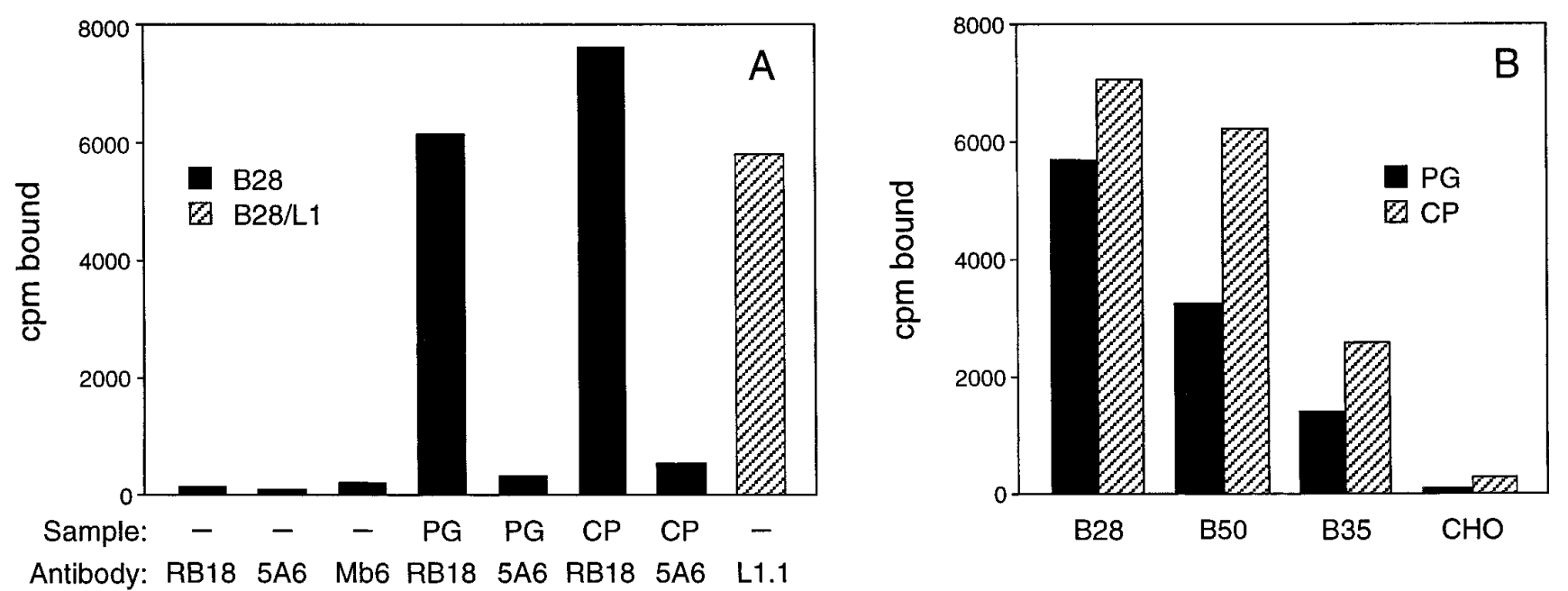

Figure 7. Exogenously added brevican binds to the surfaces of rat neural cell lines. $A$, Exogenously added brevican and brevican core protein bind to the surface of B28 cells. The binding assay was performed as described in Materials and Methods with B28 cells. Monolayers of B28 cells ( filled columns) were incubated with BSA only $(-)$, with the total soluble proteoglycan fraction $(P G)$, or with core proteins of the total soluble proteoglycan fraction $(C P)$, and the amount of brevican bound to the cells was assayed with RB18 antibodies. Control antibodies used are 5A6 and Mb6, both of IgG1 subclass. A hatched column shows the assay for cell surface L1 expressed on L1-transfected B28 cells (Dahlin-Huppe et al., 1997) for a comparison. Here the amount of L1 was measured by a similar antibody binding assay with anti-human L1 monoclonal antibody L1.1 (Dahlin-Huppe et al., 1997) and the same $\left[{ }^{125} \mathrm{I}\right]$ goat anti-mouse IgG used in the above assays. This shows that the amount of brevican bound to B28 cells is approximately comparable with that of surface-expressed L1 in L1-transfected B28 cells. Data represent means of duplicate determinations of net binding. Background binding for this experiment was 830 and $650 \mathrm{cpm}$ for B28 and L1-transfected B28 cells, respectively. B, Brevican binds to cell lines of neural origin but not to CHO cells. The binding assay was performed as described above with B28, B35, B50, and CHO cells. Monolayers of these cells were incubated with the total soluble proteoglycan fraction ( filled columns) or core proteins of the total soluble proteoglycan fraction (hatched columns). Data show means of duplicate determinations of net binding. Background binding was 720, 930, 1100, and $720 \mathrm{cpm}$ for B28, B50, B35, and CHO cells, respectively.

express only a single mRNA species for the full-length, secreted form of brevican (Yamada et al., 1994). The shorter mRNA encoding the splicing variant for the GPI-anchored isoform was not detected in these cells and therefore is considered to be a very minor component, at best. Second, PI-PLC treatment of astrocytes failed to remove cell-associated brevican from their surfaces (Fig. 6B). The amount of cell surface brevican was essentially unchanged (98 $\pm 7 \%$ of the value for untreated cells) by this treatment.

More direct evidence of the existence of brevican binding sites was obtained by assaying the binding of exogenous brevican. As shown in Figure $6 A$, with addition of intact or chondroitinasedigested brevican samples, RB18 binding to astrocytes was increased by $22 \%$ (compare third and fifth filled columns from the left) and 55\% (compare third and sixth filled columns), respectively. This indicates that there are vacant brevican binding sites on the surface of astrocytes. The binding of chondroitinasedigested brevican suggests that the binding is mediated by the core protein, not by chondroitin sulfate chains of brevican. In contrast to astrocytes, cultured granule neurons have neither cell surface brevican nor vacant brevican binding sites (hatched columns).

\section{Immortalized neural cells bind brevican by cell surface binding sites independent of hyaluronan}

To obtain further evidence of cell surface binding sites for brevican, we examined brevican binding to B28 cells, a glial cell line derived from the CNS of the BDIX rat (Schubert et al., 1974). Because B28 cells do not have endogenous brevican on their surfaces (Fig. 7A, first column from the left), the possible participation of the GPI-anchored isoform can be ruled out in these analyses. As shown in Figure $7 A$, addition of exogenous brevican resulted in significant binding of RB18 antibodies to B28 cells (fourth column from the left). Control antibodies (5A6, Mb6) showed little binding with or without exogenously added brevican samples. Treatment of the brevican samples with chondroitinase ABC did not abolish the binding (sixth column from the left), indicating that the interaction is mediated not by chondroitin sulfate chains but by the core protein of brevican, as in the case of astrocytes. The amounts of brevican bound to B28 cells were approximately comparable with the amount of L1 expressed on the surface of B28 cells transfected with human L1 cDNA (Dahlin-Huppe et al., 1997), as judged by a similar antibody binding assay (hatched column). This level of L1 expression is sufficient to transform B28 cell monolayers from a relatively inert substratum for neurite outgrowth into one that promotes abundant neurite outgrowth (W. B. Stallcup, unpublished results).

Cell surface binding of brevican is also observed in other BDIX rat-derived neural cell lines, B35 and B50, although the binding to these cells is less efficient than that to B28 cells (Fig. $7 B$ ). In both cell lines, chondroitinase digestion did not abolish the binding, indicating that the binding sites on these cells also recognize core protein. In contrast to the binding in these neural cell lines, little binding was observed in CHO cells.

Because the brevican core protein contains a hyaluronanbinding domain at its $\mathrm{N}$ terminal, it is conceivable that brevican binds to cell surface hyaluronan. To test this possibility, we performed two experiments. First, we asked whether digestion of cell surface hyaluronan with hyaluronidase could abolish the binding of exogenously added brevican. Although hyaluronidase treatment removes $>90 \%$ of cell-associated hyaluronan from B28 cells, the reduction in brevican binding was only up to $32 \%$ (Fig. $8 A$ ). Control digestion with chondroitinase $\mathrm{ABC}$ or a mixture of heparinase and heparitinase did not significantly reduce the brevican binding. These results suggest that a major portion of 

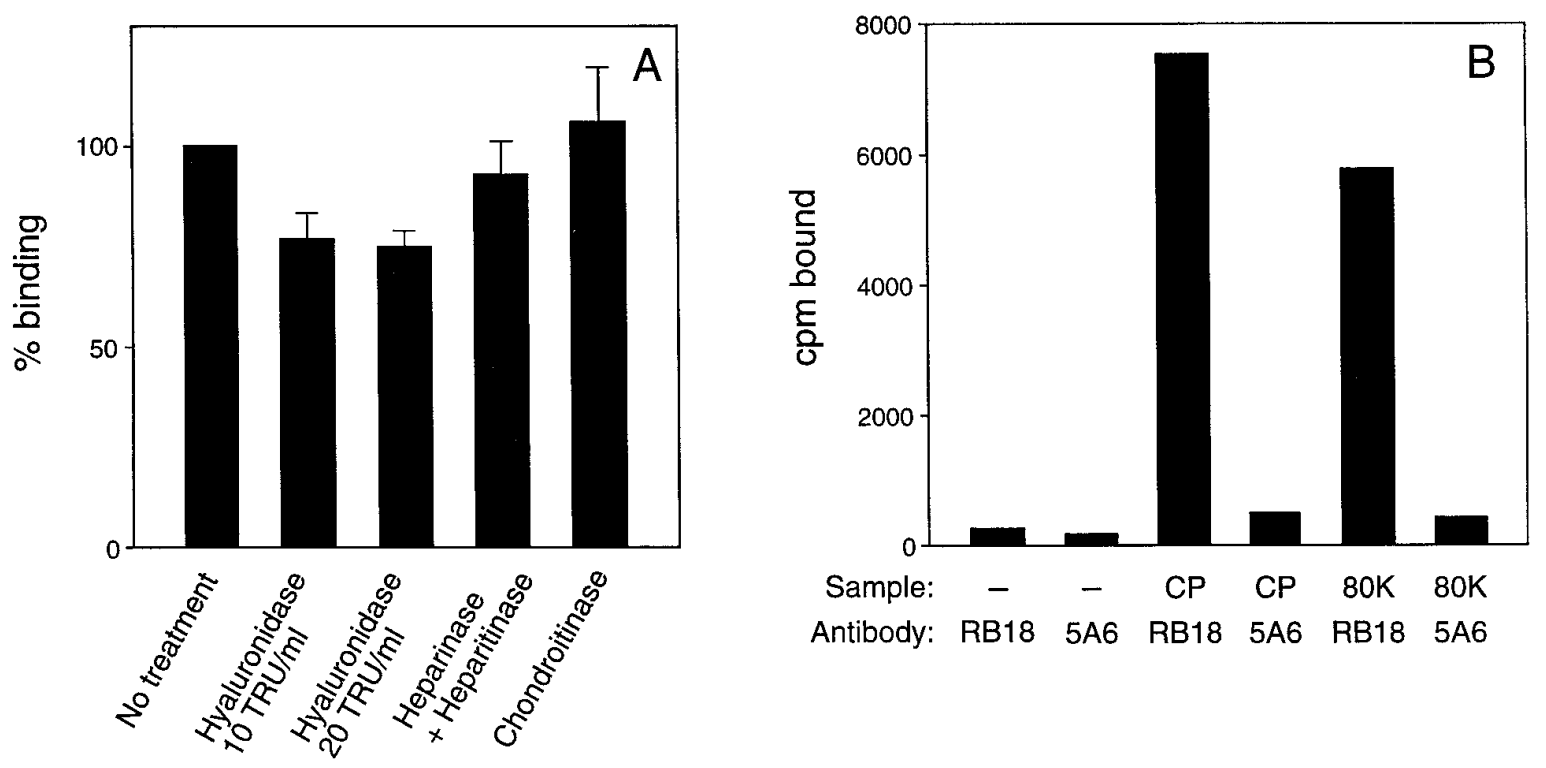

Figure 8. A major portion of the brevican binding to B28 cells is independent of cell surface hyaluronan. $A$, Hyaluronidase treatment of B28 cells does not abolish the brevican binding to the cells. Monolayers of B28 cells were treated for $1 \mathrm{hr}$ with hyaluronidase (10 and $20 \mathrm{TRU} / \mathrm{ml})$, a mixture of heparinase $(5 \mathrm{U} / \mathrm{ml})$ and heparitinase $(1 \mathrm{U} / \mathrm{ml})$, and chondroitinase ABC $(50 \mathrm{mU} / \mathrm{ml})$. The binding assay was then performed with the addition of core proteins of the total soluble proteoglycan fraction, followed by incubations with RB18 and $\left[{ }^{125} \mathrm{I}\right]$ anti-mouse $\operatorname{IgG}$. Data represent means \pm SD $(n=3)$ of percent net binding relative to the binding to cells that were not treated with enzymes (defined as $100 \%$ ). $B$, The $80 \mathrm{kDa}$ brevican core protein lacking the hyaluronan-binding domain binds B28 cells. The binding assay was performed without addition (-), with addition of core proteins of the total soluble proteoglycan fraction $(C P)$, or with addition of HPLC-purified $80 \mathrm{kDa}$ brevican core protein $(80 \mathrm{~K})$. The amount of brevican bound to the cells was assayed with RB18 antibodies. Anti-chicken B-cadherin monoclonal antibody 5A6 was used as a negative control. Data represent means of duplicate determinations of net binding.

brevican binding to B28 cells is independent of cell surface hyaluronan. Second, we examined whether the $80 \mathrm{kDa}$ fragment of brevican core protein, which lacks the hyaluronan-binding domain, binds to B28 cells. As shown in Figure $8 B$, the $80 \mathrm{kDa}$ fragment showed substantial binding to B28 cells, amounting to $\sim 75 \%$ of the binding of full-length brevican core protein (RB18 antibodies bind the full-length and the $80 \mathrm{kDa}$ core proteins equally well). Taken together, these two experiments demonstrate that $\sim 70-75 \%$ of the binding of brevican is independent of cell surface hyaluronan. These results further suggest the existence of brevican binding sites that recognize the $\mathrm{C}$-terminal domain of its core protein.

\section{Brevican inhibits neurite outgrowth from granule neurons}

Being expressed on the surface of neuroglial sheaths bordering glomeruli, brevican seems to be located at strategic sites to control the infiltration of dendrites and axons into these structures. Its late appearance during cerebellar development seems to be consistent with the possibility that brevican acts to inhibit the infiltration of dendrites and axons once a sufficient number of dendrites and axons have entered a glomerulus and formed synapses with mossy fibers. If this model for the role of brevican is valid, purified brevican isolated from adult brain should inhibit neurite outgrowth from cultured cerebellar granule neurons.

To test this model, we purified brevican from total soluble proteoglycan fractions of adult rat brain on an affinity column of RB18 antibodies (see Fig. $1 B$ ) and presented brevican to granule neurons as a substrate. On a control substrate in which BSA was mixed with laminin, granule cells attach and extend neurites as effectively as on a laminin-only substrate (Fig. 9A,B). On the brevican substrate, granule cells are not able to attach to the dish even in the presence of laminin (Fig. $9 C, D)$. Neurite outgrowth was inhibited at the border between the brevican and laminin mixture and the laminin-only substrate. In a substrate prepared from a mixture of $100 \mu \mathrm{g} / \mathrm{ml}$ brevican and $50 \mu \mathrm{g} / \mathrm{ml}$ laminin, no granule cells were able to attach to the substrate, and no neurites were extended into the test substrate (Fig. 9C). The inhibitory effect of brevican was also apparent in a substrate prepared from $50 \mu \mathrm{g} / \mathrm{ml}$ brevican and $50 \mu \mathrm{g} / \mathrm{ml}$ laminin, although at this concentration of brevican a few granule cells attach and extend neurites (Fig. 9D). In contrast, the substrate of brevican core protein prepared by chondroitinase digestion almost entirely lacks inhibitory effects (Fig. 9E,F).

\section{DISCUSSION}

In this paper, we attempt to gain insight into the role of brevican in the brain by investigating its spatiotemporal expression in developing rat cerebellum. In summary, these studies demonstrate the following: (1) the deposition of brevican occurs predominantly in the granular layer after the migration of granule cells has been completed; (2) brevican is localized on the surface of astrocytes that form neuroglial sheaths surrounding glomeruli; (3) brevican mRNA is expressed by these astrocytes; (4) cerebellar astrocytes in culture anchor endogenous brevican on their surface; (5) cerebellar astrocytes have cell surface binding sites for brevican core protein; and (6) brevican inhibits neurite outgrowth from cerebellar granule cells in vitro. Based on these results, we suggest that brevican is expressed by and deposited on astrocytes ensheathing glomeruli as a means of controlling the infiltration of dendrites and axons into maturing glomeruli.

The glomerulus is a strategic site for neuronal connectivity in the cerebellar cortex. In glomeruli, mossy fiber axons originating from various regions of the CNS form synapses with cerebellar interneurons, granule cells, and Golgi cells. The dendrites of 

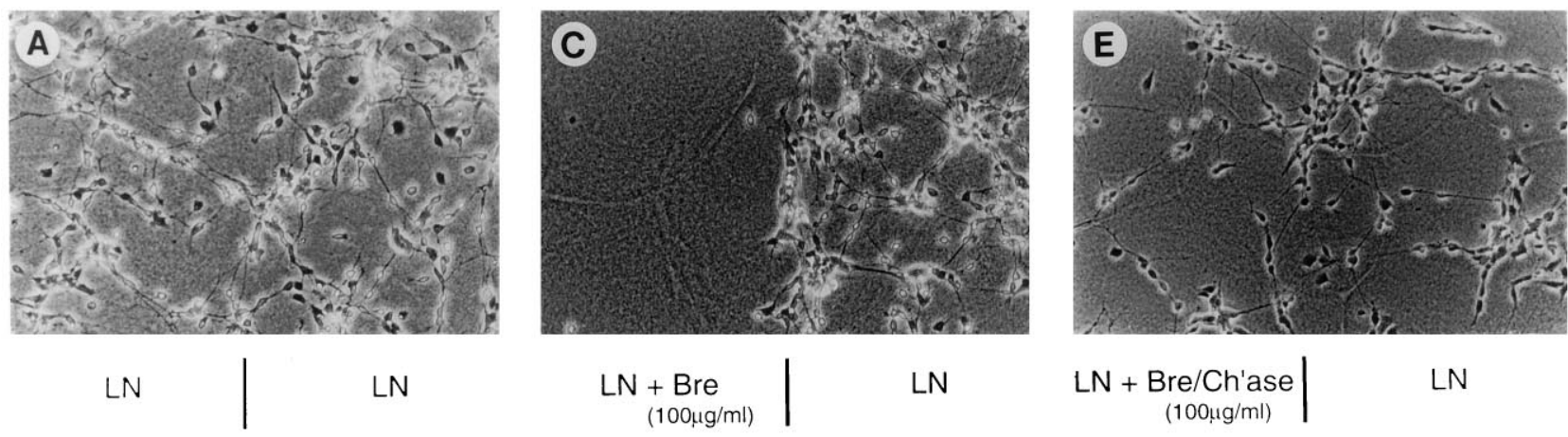

$$
\underset{(100 \mu \mathrm{g} / \mathrm{ml})}{\mathrm{LN}+\mathrm{Bre}}|\quad \mathrm{LN} \quad \mathrm{LN}+\underset{(100 \mu \mathrm{g} / \mathrm{ml})}{\mathrm{Bre} / \mathrm{Ch}}|
$$

LN

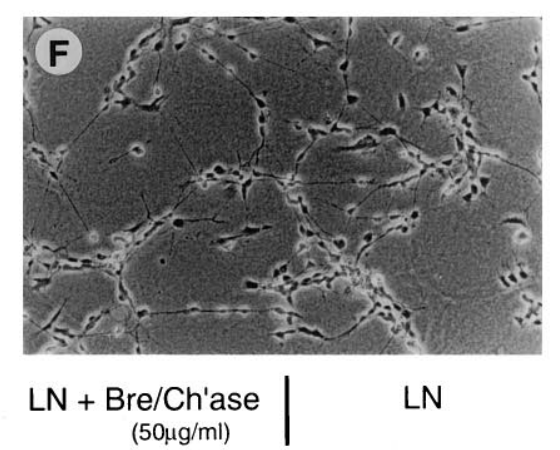

$(50 \mu \mathrm{g} / \mathrm{ml})$

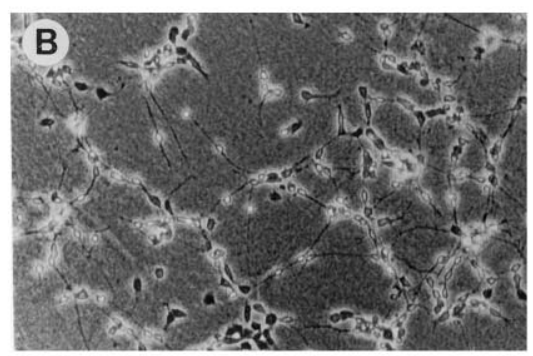

$$
\mathrm{LN}+\mathrm{BSA}
$$

(100بg ml)

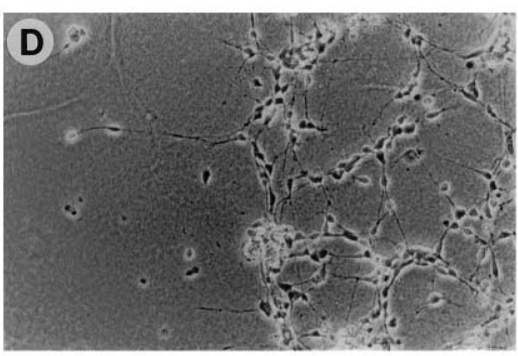

LN $\underset{(50 \mu \mathrm{g} / \mathrm{ml})}{\mathrm{LN}+\mathrm{Bre}}$

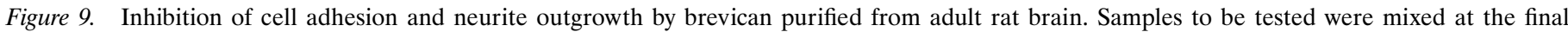

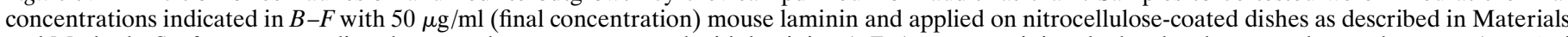

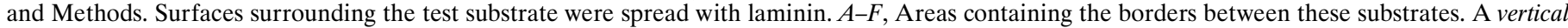

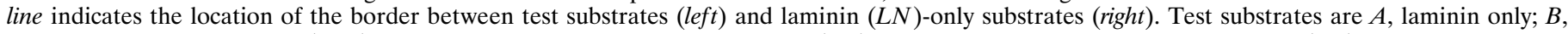

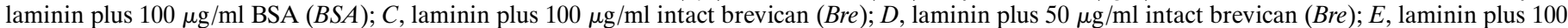
$\mu \mathrm{g} / \mathrm{ml}$ chondroitinase ABC-digested brevican (Bre/Ch'ase); and $F$, laminin plus $50 \mu \mathrm{g} / \mathrm{ml}$ chondroitinase ABC-digested brevican (Bre/Ch'ase).

granule cells and the axons of Golgi cells swirl around the mossy fiber, forming characteristic rosettes (Altman, 1972; Palay and Chan-Palay, 1974; Landis et al., 1983). A type of astrocyte called the velate protoplasmic astrocyte (Palay and Chan-Palay, 1974) forms a sheath covering each glomerulus (Palay and Chan-Palay, 1974; Landis et al., 1983). Lamellar processes of these astrocytes separate one glomerulus from another in the islet and interweave with the dendrites and Golgi cell axons at the periphery of the glomerulus (Palay and Chan-Palay, 1974).

The localization of brevican immunoreactivity demonstrated at light and electron microscopic levels is in good agreement with the location of these processes of velate protoplasmic astrocytes. Furthermore, in situ hybridization has shown that these astrocytes express brevican mRNA. Taken together, these results suggest that brevican is produced by velate protoplasmic astrocytes forming neuroglial sheaths and then is deposited on their surfaces. Our observation that cultured astrocytes possess endogenously produced brevican on their surfaces is consistent with this model.

Altman (1972) reported that three stages, namely, the morphogenic, synaptogenic, and gliogenic stages, can be distinguished in the development of the granular layer. The bulk of extension of granule cell dendrites and of synapse formation in the glomeruli occurs in the third postnatal week. Gliogenesis follows, signaling the end of the stage of dendrite extension and synapse formation. We demonstrate that the emergence of strong brevican immunoreactivity in glomeruli occurs after the end of the third week. Thus our results suggest that the temporal expression of brevican corresponds to the maturing stage of the glomerulus that is characterized by glial differentiation. This notion is consistent with the observation by Jaworski et al. (1995) that the expression of BEHAB mRNA (which is now known to represent a partial brevican cDNA) generally coincides with gliogenic stages of the developing rat nervous system. Although these workers demonstrated in several parts of the rat nervous system that the expression of BEHAB mRNA begins much earlier than we detect brevican immunoreactivity, this is probably attributable to the early onset of gliogenesis in these areas and to the possible time lag between mRNA expression and the accumulation of detectable amounts of protein products.

The role of the neuroglial sheaths is still a subject of much speculation and controversy based on little solid evidence (see, e.g., Palay and Chan-Palay, 1974). Among postulated roles for the neuroglial sheaths are structural support, electrophysiological insulation of individual glomeruli, and the maintenance of chemical equilibrium in the interstitial fluid (Ramon y Cajal, 1912; Palay and Chan-Palay, 1974; Jacobson, 1991; Peters et al., 1991). Our findings described in this paper suggest another putative role for the neuroglial sheath; neuroglial sheaths presenting brevican on their surfaces may act as barriers to granule cell dendrites and Golgi cell axons. The formation of neuroglial sheaths, which occurs after the third postnatal week, corresponds to the waning phase of dendrite extension (Altman, 1972). Emergence of strong brevican immunoreactivity also corresponds to this period. The neurite outgrowth inhibitory activity of brevican is consistent with such a role for neuroglial sheaths. Thus, it is possible that brevican on the surface of neuroglial sheaths may act to prevent the infiltration of excess numbers of dendrites and axons once appropriate numbers of them have previously formed synapses with mossy fibers. In this context, it is interesting to note that 
there are several reports suggesting that the ability of astrocytes to support neurite outgrowth may depend on the maturation and the expression of CSPGs in these cells. For example, Goodman et al. (1993) reported that olfactory bulb astrocytes from adult rats support lower levels of neurite outgrowth than those from neonatal rats. In addition, a subpopulation of astrocytes producing a larger amount of CSPGs supports lower levels of neurite outgrowth (Meiners et al., 1995), and the inhibition of proteoglycan synthesis with xyloside makes primary astrocytes more permissive to neurite outgrowth (Fok-Seang et al., 1995).

It should be noted that, although abundantly expressed in velate protoplasmic astrocytes, brevican is not expressed in Golgi epithelial cells, another prominent glial cell type in cerebellar cortex. The lack of staining in the adult white matter also suggests that brevican is not highly expressed in oligodendrocytes in adult cerebellum, although it is expressed in P21 white matter. These observations indicate that the expression of brevican is not ubiquitous in all glial cell types. This expression pattern of brevican is in contrast to that of neurocan. It has been shown that, in adult rat cerebellum, neurocan immunoreactivity is strongest in the molecular layer and the white matter. The Bergmann glial fibers are also positively stained (Rauch et al., 1991). Temporally, the appearance of neurocan expression in the rat cerebellum is significantly earlier than that of brevican expression; strong staining is already seen at P7 (Rauch et al., 1991; Friedlander et al., 1994; Grumet et al., 1994). Although the spatiotemporal expression patterns of the other two lecticans (aggrecan and versican) in the developing cerebellum have not been established, these observations suggest that the expression of lectican family CSPGs is differentially regulated.

We have demonstrated that endogenous brevican is present on the surface of primary astrocytes and that these cell surface brevican molecules are not the GPI-anchored isoform. This was somewhat surprising, considering that brevican is a secreted proteoglycan. Yet several lines of evidence described in Results indicate that there are vacant brevican binding sites on the surface of primary astrocytes and several neural cell lines. Although we have not performed quantitative analysis of the interaction, in comparison with the levels of other cell surface molecules found in B28 cells, the levels of brevican binding seem high enough to be physiologically significant. For example, the amounts of brevican bound to B28 cells were approximately comparable with the amount of L1 sufficient to promote abundant neurite outgrowth (see Fig. 7). The putative cell surface "brevican receptor" recognizes the C-terminal portion of the brevican core protein and is independent of cell surface hyaluronan. Because the C-type lectin domains of all four lecticans bind the extracellular matrix protein tenascin-R (Aspberg et al., 1997), it is conceivable that the cell surface binding site for brevican might be tenascin-R deposited on the surface. However, it seems highly unlikely because no tenascin- $\mathrm{R}$ was detected on the surface of B28 cells, as demonstrated by fluorescence-activated cell sorting and immunocytochemical analyses, or in culture supernatants or lysates of B28 cells (R. Miura and Y. Yamaguchi, unpublished results). At present, the identity of the putative cell surface receptor has not been elucidated. Because the $\mathrm{C}$-terminal domain of brevican contains a C-type lectin domain, it is possible that certain cell surface carbohydrates are involved in the interaction with brevican.

Whatever the molecular mechanism of the interaction, cell surface association of brevican may have broad implications for the way in which secreted CSPGs with neurite outgrowth inhib- itory activity exert their effects on growing axons and dendrites. In vivo, the inhibition of axon growth often occurs when growing axons encounter histologically well defined areas that have inhibitory activities. Such histological structures are called barriers, and CSPGs have been implicated as active barrier components. This type of spatially restricted distribution of inhibitory activities is thought to be crucial for the accurate control of axon guidance at specific sites in the developing nervous system. Yet most CSPGs are secreted molecules without intrinsic anchorage to cell surfaces. The type of cell surface association that we have observed for brevican may be a general paradigm for restricting the distribution of neurite outgrowth inhibitory activities of secreted CSPGs to certain developmentally strategic sites.

\section{REFERENCES}

Akeson R, Warren SL (1986) PC12 adhesion and neurite formation on selected substrates are inhibited by some glycosaminoglycans and a fibronectin-derived tripeptide. Exp Cell Res 162:347-362.

Altman J (1972) Postnatal development of the cerebellar cortex in the rat. III. Maturation of the components of the granular layer. J Comp Neurol 145:465-514.

Aspberg A, Miura R, Bourdoulous S, Shimonaka M, Heinegård D, Schachner M, Ruoslahti E, Yamaguchi Y (1997) The C-type lectin domains of lecticans, a family of aggregating chondroitin sulfate proteoglycans, bind tenascin- $\mathrm{R}$ by protein-protein interactions independent of carbohydrate moiety. Proc Natl Acad Sci USA, in press.

Barsony J, Marx SJ (1990) Immunocytology on microwave-fixed cells reveals rapid and agonist-specific changes in subcellular accumulation patterns for cAMP or cGMP. Proc Natl Acad Sci USA 87:1188-1192.

Bode-Lesniewska B, Dours-Zimmermann MT, Odermatt BF, Briner J, Heitz PU, Zimmermann DR (1996) Distribution of the large aggregating proteoglycan versican in adult human tissues. J Histochem Cytochem 44:303-312.

Brittis PA, Canning DR, Silver J (1992) Chondroitin sulfate as a regulator of neuronal patterning in the retina. Science 225:733-736.

Carbonetto S, Gruver MN, Turner DC (1983) Nerve fiber growth in culture on fibronectin, collagen, and glycosaminoglycan substrates. J Neurosci 3:2324-2335.

Couchman JR, Caterson B, Christfer JE, Baker JR (1984) Mapping by monoclonal antibody detection of glycosaminoglycans in connective tissues. Nature 307:650-652.

Dahlin-Huppe K, Berglund EO, Ranscht B, Stallcup WB (1997) Mutational analysis of the L1 neuronal cell adhesion molecule identifies membrane-proximal amino acids of the cytoplasmic domain that are required for cytoskeletal anchorage. Mol Cell Neurosci 9:144-156.

De Block M, Debrouwer D (1993) RNA-RNA in situ hybridization using digoxigenin-labeled probes: the use of high-molecular-weight polyvinyl alcohol in the alkaline phosphatase indoxyl-nitroblue tetrazolium reaction. Anal Biochem 215:86-89.

Doege K, Sasaki M, Horigan E, Hassel JR, Yamada Y (1987) Complete primary structure of the rat cartilage proteoglycan core protein deduced from cDNA clones. J Biol Chem 262:17757-17767.

Faissner A, Clement A, Lochter A, Striet A, Mandl C, Schachner M (1994) Isolation of a neural chondroitin sulfate proteoglycan with neurite outgrowth promoting properties. J Cell Biol 126:783-799.

Fok-Seang J, Smith-Thomas LC, Meiners S, Muir E, Du JS, Housden E, Johnson AR, Faissner A, Geller HM, Keys RJ, Rogers JH, Fawcett JW (1995) An analysis of astrocytic cell lines with different abilities to promote axon growth. Brain Res 689:207-223.

Friedlander DR, Milev P, Karthikeyan L, Margolis RK, Margolis RU (1994) The neuronal chondroitin sulfate proteoglycan neurocan binds to the neural cell adhesion molecule Ng-CAM/liter1/NILE and NCAM, and inhibits neuronal adhesion and neurite outgrowth. J Cell Biol 125:669-680.

Goodman MN, Silver J, Jacobberger JW (1993) Establishment and neurite outgrowth properties of neonatal and adult rat olfactory bulb glial cell lines. Brain Res 619:199-213.

Grumet M, Milev P, Sakurai T, Karthikeyan L, Bourdon M, Margolis RK, Margolis RU (1994) Interactions with tenascin and differential effects on cell adhesion of neurocan and phosphacan, two major chondroitin sulfate proteoglycans of nervous tissue. J Biol Chem 269:12142-12146. Herndon ME, Lander AD (1990) A diverse set of developmentally reg- 
ulated proteoglycans is expressed in the rat central nervous system. Neuron 4:949-961.

Jacobson M (1991) Developmental neurobiology, Ed 3. New York: Plenum.

Jaworski DM, Kelly GM, Hockfield S (1994) BEHAB, a new member of the proteoglycan tandem repeat family of hyaluronan-binding proteins that is restricted to the brain. J Cell Biol 125:495-509.

Jaworski DM, Kelly GM, Hockfield S (1995) The CNS-specific hyaluronan binding protein $\mathrm{BEHAB}$ is expressed in ventricular zones coincident with gliogenesis. J Neurosci 15:1352-1362.

Katoh-Semba R, Oohira A (1993) Core proteins of soluble chondroitin sulfate proteoglycans purified from the rat brain block the cell cycle of PC12D cells. J Cell Physiol 156:17-23.

Koller E, Ranscht B (1996) Differential targeting of T- and N-cadherin in polarized epithelial cells. J Biol Chem 271:30061-30067.

Landis DMD, Weinstein LA, Halperin JJ (1983) Development of synaptic junctions in cerebellar glomeruli. Brain Res 284:231-245.

Li H, Domowicz M, Hennig A, Schwartz NB (1996) S103L reactive chondroitin sulfate proteoglycan (aggrecan) mRNA expressed in developing chick brain and cartilage is encoded by a single gene. Brain Res Mol Brain Res 36:309-321.

Margolis RK, Margolis RU (1993) Nervous tissue proteoglycans. Experientia 49:429-446.

McCarthy KD, de Vellis J (1980) Preparation of separate astroglial and oligodendroglial cell cultures from rat cerebral tissue. J Cell Biol 85:890-902.

Meiners S, Powell EM, Geller HM (1995) A distinct subset of tenascin/ CS-6-PG-rich astrocytes restricts neuronal growth in vitro. J Neurosci 15:8096-8108.

Murphy-Erdosh C, Napolitano EW, Reichardt LF (1994) The expression of B-cadherin during embryonic chick development. Dev Biol 161:107-125.

Nilsson K, Mosbach K (1984) Immobilization of ligands with organic sulfonyl chlorides. Methods Enzymol 104:65-78.

Oakley RA, Tosney KW (1991) Peanut agglutinin and chondroitin-6sulfate are molecular markers for tissues that act as barriers to axon advance in the avian embryo. Dev Biol 147:187-206.

Palay SL, Chan-Palay V (1974) Cerebellar cortex: cytology and organization. New York: Springer.

Perris R, Krotoski D, Lallier T, Domingo C, Sorrel JM, Bronner-Fraser M (1991) Spatial and temporal changes in the distribution of proteoglycans during avian neural crest development. Development 111:583-599.

Peters A, Palay SL, Webster HD (1991) The fine structure of the nervous system: neurons and their supporting cells, Ed 3. New York: Oxford UP.

Ramon y Cajal S (1912) Histology of the nervous system of man and vertebrates. Reprint (Swanson N, Swanson LW, translators), History of neuroscience, No 6, Vol 1. New York: Oxford UP, 1995.

Rauch U, Gao P, Janetzko A, Flaccus A, Hilgenberg L, Tekotte H, Margolis RK, Margolis RU (1991) Isolation and characterization of developmentally regulated chondroitin sulfate and chondroitin/keratan sulfate proteoglycans of brain identified with monoclonal antibodies. J Biol Chem 266:14785-14801.

Rauch U, Karthikeyan L, Maurel P, Margolis RU, Margolis RK (1992) Cloning and primary structure of neurocan, a developmentally regulated, aggregating chondroitin sulfate proteoglycan of brain. J Biol Chem 267:19536-19547.

Ruoslahti E (1996) Brain extracellular matrix. Glycobiology 6:489-492.

Schubert D, Heinemann S, Carlisle W, Tarikas H, Kimes B, Patrick J, Steinbach JH, Culp W, Brandt BL (1974) Clonal cell lines from the rat central nervous system. Nature 249:224-227.

Seidenbecher CI, Richter K, Rauch U, Fässler R, Garner CC, Gundelfinger ED (1995) Brevican, a chondroitin sulfate proteoglycan of rat brain, occurs as secreted and cell surface glycosylphosphatidylinositolanchored isoforms. J Biol Chem 270:27206-27212.

Snow DM, Lemmon V, Carrino DA, Caplan AI, Silver J (1990) Sulfated proteoglycans in astroglial barriers inhibit neurite outgrowth in vitro. Exp Neurobiol 109:111-130.

Snow DM, Watanabe M, Letourneau PC, Silver J (1991) A chondroitin sulfate proteoglycan may influence the direction of retinal ganglion cell outgrowth. Development 113:1473-1485.

Stallcup WB, Beasley L (1985) Involvement of the nerve growth factorinducible large external glycoprotein (NILE) in neurite fasciculation in primary cultures of rat brain. Proc Natl Acad Sci USA 82:1276-1280.

Takayama C (1994) Altered distribution of inhibitory synaptic terminals in reeler cerebellum with special references to malposition of GABAergic neurons. Neurosci Res 20:239-250.

Verna JM, Fichard A, Saxod R (1989) Influence of glycosaminoglycans on neurite morphology and outgrowth patterns in vitro. Int $\mathrm{J}$ Dev Neurosci 7:389-399.

Watanabe K, Yamaguchi Y (1996) Molecular identification of a putative human hyaluronan synthase. J Biol Chem 271:22945-22948.

Watanabe K, Yamada H, Yamaguchi Y (1995) K-glypican: a novel GPIanchored heparan sulfate proteoglycan that is highly expressed in developing brain and kidney. J Cell Biol 130:1207-1218.

Yamada H, Watanabe K, Shimonaka M, Yamaguchi Y (1994) Molecular cloning of brevican, a novel brain proteoglycan of the aggrecan/versican family. J Biol Chem 269:10119-10126.

Yamada H, Watanabe K, Shimonaka M, Yamaguchi Y (1995) cDNA cloning and the identification of an aggrecanase-like cleavage site in rat brevican. Biochem Biophys Res Commun 216:957-963.

Zimmermann DR, Ruoslahti E (1989) Multiple domains of the large fibroblast proteoglycan, versican. EMBO J 8:2975-2981. 